\title{
Genotype × Environment Interaction for Milk Yield in Holsteins Using Luxembourg and Tunisian Populations
}

\author{
H. Hammami, ${ }^{*} †$ B. Rekik, $\ddagger$ H. Soyeurt, ${ }^{*}$ C. Bastin, ${ }^{*}$ J. Stoll, $\S$ and N. Gengler*\# ${ }^{1}$ \\ *Animal Science Unit, Gembloux Agricultural University, B-5030 Gembloux, Belgium \\ †Livestock and Pasture Office, 1002 Tunis Belvedere, Tunisia \\ †Ecole Supérieure d'Agriculture de Mateur, 7030 Mateur, Tunisia \\ $\S C O N V I S$ Herdbuch, Service Elevage et Génétique, L-9004 Ettelbruck, Luxembourg \\ \#National Fund for Scientific Research, B-1000 Brussels, Belgium
}

\section{ABSTRACT}

Test-day (TD) milk yield records of first-lactation Holstein cows in Luxembourg and Tunisia were analyzed using within- and between-country random regression TD models. Edited data used for within-country analysis included 661,453 and 281,913 TD records in Luxembourg and Tunisia, respectively. The joint data included 730,810 TD records of 87,734 cows and 231 common sires. Both data sets covered calving years 1995 to 2006. Fourth-order Legendre polynomials for random effects and a Gibbs sampling method were used to estimate variance components of lactation curve parameters in separate and joint analyses. Genetic variances of the first 3 coefficients from Luxembourg data were 46 to $69 \%$ larger than corresponding estimates from the Tunisian data. Inversely, the Tunisian permanent environment variances for the same coefficients were 52 to $65 \%$ larger than the Luxembourg ones. Posterior mean heritabilities of 305-d milk yield and persistency, defined as estimated breeding values (EBV) at 280 days in milk - EBV at 80 days in milk, from between-country analysis were 0.42 and 0.12 and 0.19 and 0.08 in Luxembourg and Tunisia, respectively. Heritability estimates for the same traits from withincountry analyses, mainly from the Tunisian data, were lower than those from the joint analysis. Genetic correlations for 305-d milk yield and persistency between countries were 0.60 and 0.36 . Product moment and rank correlations between EBV of common sires for 305-d milk yield and persistency from within-country analyses were 0.38 and 0.41 and 0.27 and 0.26 , respectively. Differences between genetic variances found in both countries reflect different milk production levels. Moreover, low genetic and rank correlations suggest different ranking of sires in the 2 environments, which

Received March 4, 2008.

Accepted May 28, 2008.

${ }^{1}$ Corresponding author: gengler.n@fsagx.ac.be implies the existence of a genotype $\times$ environment interaction for milk yield in Holsteins.

Key words: milk yield, genetic parameter, genotype $\times$ environment interaction, Holstein

\section{INTRODUCTION}

Several countries with developing dairy industries have opted for the importation of semen and heifers to replace indigenous breeds. The high-yielding Holstein is the most popular among all dairy breeds worldwide. This strategy would be effective if imported animals performed as well in less favorable management circumstances, as they would in the environments in which they were selected. Banos and Smith (1991) reported that unfavorable genotype $\times$ environment interaction $(\mathbf{G} \times \mathbf{E})$ would decrease potential benefits from a strategy based on the importation of superior germplasm. Payne and Hodges (1997) also reported that ignoring $\mathrm{G} \times \mathrm{E}$ when production environments in exporting and importing countries vary widely can lead to expensive failures.

It has been found that $\mathrm{G} \times \mathrm{E}$ occurs when the performance of different genotypes is not identically affected by different environments. The definition of environment should not include only physical and climatic conditions, but also production and health management, economic constraints, and prevailing agricultural policies (Stanton et al., 1991). Studies on G $\times$ E vary from controlled experiments with a few hundred animals (Veerkamp et al., 1995; Beerda et al., 2007) to modeling large field data sets (Weigel et al., 2001; Zwald et al., 2003). Only scaling effects caused by heterogeneous genetic variances were reported by almost all within-country analyses of milk yield in Holsteins (Calus et al., 2002; Raffrenato et al., 2003; Fahey et al., 2007). Furthermore, high genetic correlations were found between countries from the same ecological zone (Weigel et al., 2001) with no evidence of $\mathrm{G} \times \mathrm{E}$. On the other hand, studies on $\mathrm{G} \times \mathrm{E}$ between countries with different climatic conditions and production systems 
(Stanton et al., 1991; Costa et al., 2000; Ojango and Pollott, 2002) were rare. In these studies, genetic correlations between countries suggest the existence of $\mathrm{G}$ $\times \mathrm{E}$ for milk yield in Holsteins. Moreover, Stanton et al. (1991) and Costa et al. (2000) found that the response to selection was smaller in low-input systems than in high-input ones.

Milk yield has been the main breeding objective in Tunisia, whereas a composite index that includes durability, health, and reproduction traits in addition to milk yield is the selection criterion currently used in Luxembourg (Miglior et al., 2005). The Luxembourg Holstein population originally included one-third non-Holstein Red and White dairy cows. Breeders in Luxembourg imported heifers mainly from Germany. Tunisia started importing purebred pregnant Friesian heifers from the Netherlands in 1970. Holstein semen and heifers were then imported from Canada, the United States, and some European countries (Hammami et al., 2007). As in Tunisia, breeders in Luxembourg are currently using semen from mostly North American and European Holstein sires. Therefore, average additive genetic relationships and genetic similarity between the Luxembourg and Tunisian cow populations have increased with time as a result of continuously using common sires proven in foreign high-input environments (Hammami et al., 2007). The Tunisian environment can be described as a low- to medium-input system, whereas the Luxembourg one can be described as a high-input system. Quantifying interactions between imported germplasm and Luxembourg and Tunisian environments is important for both populations to evaluate and adjust their breeding strategies if necessary. The objective of this study was to assess $\mathrm{G} \times \mathrm{E}$ for first-lactation milk yield in Holsteins using Luxembourg and Tunisian field data.

\section{MATERIALS AND METHODS}

\section{Data}

First-lactation test-day (TD) records were available for Luxembourg and Tunisian Holstein cows from 1995 to 2006. Luxembourg data were provided by United Datasystems for Animal Production (Vereinigte Informationssyteme Tierhaltung, Verden, Germany). Data were collected from herds under official milk recording by CONVIS Herdbuch, Service Elevage et Génétique, Ettelbruck, Luxembourg. This data set included 852,273 TD records. Tunisian data were obtained from the official milk recording maintained by the Center for Genetic Improvement of the Livestock and Pasture Office and included 306,415 TD records. Retained records from the Luxembourg and Tunisian data sets were those of cows with known sires and having at least 5 TD records between 5 and 330 DIM. Records from herds with less than $4 \mathrm{yr}$ of performance data were omitted. Furthermore, only herd-year subclasses with at least 4 cow records were kept. After editing, the remaining data for both the Luxembourg and Tunisian cow populations included 943,366 TD records of 114,025 cows. Data structures and descriptive characteristics are given in Table 1.

A combined pedigree file was also created from the Luxembourg and Tunisian source files and by crosschecking with international pedigree files (Hammami et al., 2007). This file included genealogical records on 166,980 animals born between 1927 and 2004. Total numbers of sires with progeny records were 2,546 and 2,035 in Luxembourg and Tunisia, respectively. To create a data set that maximized links without destroying initial data structure, the following strategy was used. First, we selected common sires with at least 4 daughters in each country. These sires are called common sires throughout the study. Herds with daughters of common sires were identified in both populations. Data used in the joint analysis contained all records from these herds, on daughters from common and other sires. The final joint data included 730,810 TD records of 87,734 cows.

Age at calving and the calving season were defined to account for specificities of each population. Four seasons (September to November, December to February, March to May, and June to August) for Tunisia and 3 seasons (January to March, April to August, September to December) for Luxembourg were identified. Additionally, age at calving was classified into 5 classes $(<28 \mathrm{mo}, 28$ to 30,31 to 33,34 to 36 , and $>36$ $\mathrm{mo})$ for the Luxembourg population and 6 classes $(<26$ mo, 26 to 27,28 to 29,30 to 31,32 to 33 , and $>33 \mathrm{mo}$ ) for the Tunisian population, respectively. Different age at calving classes were used to account for dissimilar ranges of calving age in the 2 countries (Table 1 ).

\section{Analysis}

Genetic parameters and evaluations were obtained from single and joint analyses of Luxembourg and Tunisian data by a random regression TD animal model. In matrix notation, the within-country model was:

$$
\mathbf{y}=\mathbf{X b}+\mathbf{Q}(\mathbf{Z a}+\mathbf{Z} \mathbf{p}+\mathbf{W h})+\mathbf{e}
$$

where $\mathbf{y}=$ a vector of TD milk yields; $\mathbf{b}=$ a vector of the fixed effects: herd $\times$ test-date, age $\times$ season of calving $\times$ classes of 25 DIM, and classes of 5 DIM; $\mathbf{a}=$ a vector of random regression coefficients for animal genetic (AG) effect; $\mathbf{p}=$ a vector of random regression coefficients for 
Table 1. Production descriptors ${ }^{1,2}$ (with SD in parentheses) and some environmental characteristics ${ }^{3}$ for the Luxembourg and Tunisian Holstein populations

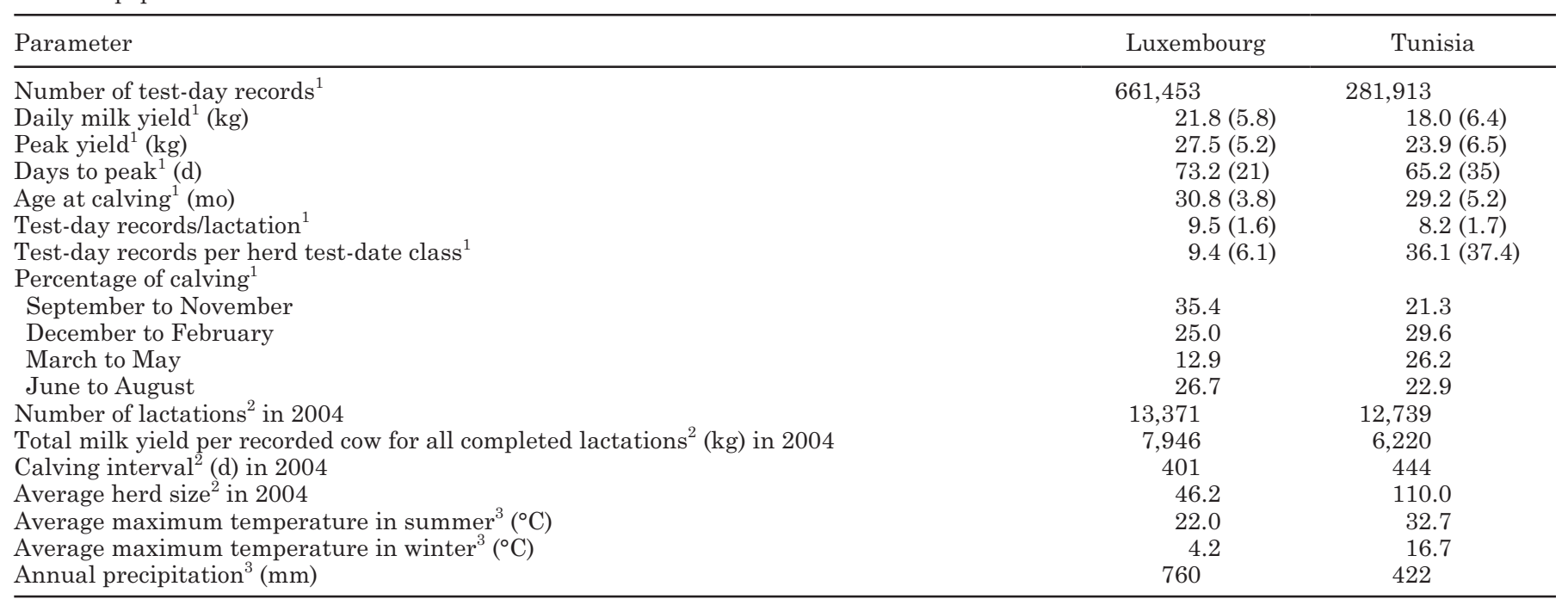

${ }^{1}$ First-lactation parameters from the within-country data sets.

${ }^{2}$ Figures from ICAR (2007) based on national performance recording statistics.

${ }^{3}$ Figures from Freemeteo (2007).

permanent environmental (PE) effect; $\mathbf{h}=\mathbf{a}$ vector of random regression coefficients for herd-year of calving common environmental effect $(\mathbf{H Y})$; $\mathbf{e}=$ a vector of residual effects; $\mathbf{Q}=$ a matrix of Legendre polynomials; and $\mathbf{X}, \mathbf{Z}$, and $\mathbf{W}=$ incidence matrices relating observations to various effects. Residuals were assumed to be constant within DIM intervals. Legendre polynomials were of order 4 with: $\mathrm{q}_{\mathrm{t} 0}=1, \mathrm{q}_{\mathrm{t} 1}=\sqrt{3} \mathrm{x}$, $\mathrm{q}_{\mathrm{t} 2}=\sqrt{5}\left(1.5 \mathrm{x}^{2}-0.5\right), \quad \mathrm{q}_{\mathrm{t} 3}=\sqrt{7}\left(2.5 \mathrm{x}^{3}-1.5 \mathrm{x}\right), \quad$ a $\quad \mathrm{n} \quad \mathrm{d}$ $\mathrm{q}_{\mathrm{t} 4}=\sqrt{9}\left(35 \mathrm{x}^{4}-30 \mathrm{x}^{2}+3\right) / 8$, where $\mathrm{x}=-1+(\mathrm{t}-1) /(330$ $-1)$ and $t=$ DIM. Higher order polynomials were used in this study than by Hammami et al. (2008), because extreme values for the genetic variance at the beginning and end of lactation were found in that study. Higher-order regressions allowed testing the hypothesis that they better modeled variance curves across lactation (Pool et al., 2000). An equal order of fit for $\mathrm{AG}, \mathrm{PE}$, and $\mathrm{HY}$ was used to provide equal opportunity of variation for all components.

The same model from above was used for the joint analysis but was extended to a bivariate model; records from Luxembourg and Tunisia being considered 2 distinct, correlated traits. Definitions of fixed and random effects remained the same but were trait-specific and nested within country.

Expectations and covariance structure for random effects were defined as follows:

$$
\mathbf{E}(\mathbf{y})=\mathbf{X b}, \mathbf{E}(\mathbf{a})=\mathbf{0}, \mathbf{E}(\mathbf{p})=\mathbf{0}, \mathbf{E}(\mathbf{h})=\mathbf{0}, \mathbf{E}(\mathbf{e})=\mathbf{0},
$$

and

$$
\mathrm{V}(\mathbf{a})=\mathbf{G}, \mathrm{V}(\mathbf{p})=\mathbf{P}, \mathrm{V}(\mathbf{h})=\mathbf{H}, \mathrm{V}(\mathbf{e})=\mathbf{E},
$$

where $\mathbf{G}=\mathbf{A} \otimes \mathbf{G}_{\mathbf{0}}, \mathbf{P}=\mathbf{I} \otimes \mathbf{P}_{\mathbf{0}}, \mathbf{H}=\mathbf{I} \otimes \mathbf{H}_{\mathbf{0}} ; \mathbf{A}=$ the additive genetic relationship matrix; $\mathbf{G}_{\mathbf{0}}, \mathbf{P}_{\mathbf{0}}$, and $\mathbf{H}_{\mathbf{0}}=10$ $\times 10$ covariance matrices for $\mathrm{AG}, \mathrm{PE}$, and $\mathrm{HY}$ regression coefficients, respectively. All between-country covariances in $\mathbf{P}_{\mathbf{0}}$ and $\mathbf{H}_{\mathbf{0}}$ were equal to zero, because no herd spans across countries, and we assumed no cow moved between Tunisia and Luxembourg during its first lactation. The matrix $\mathbf{E}$ was considered to be diagonal, representing residual variances for milk yield in Luxembourg and Tunisia.

Genetic parameters from both single and 2-country models were estimated with a Bayesian approach via a Gibbs sampling algorithm (Misztal et al., 2002). Single chains of 120,000 samples (with 20,000 discarded) were generated for separate analyses on the data of each country. For the joint analysis, a chain of 160,000 samples (with 30,000 as burn-in period) was generated. Convergence of Gibbs chains was monitored by inspecting plots of selected realizations.

Persistency of lactation can be defined as the ability of a cow to maintain milk production after peak yield. This parameter was defined in various ways in the literature (Gengler, 1996), with no consensus reached yet on the suitable definition. Lately, this parameter has been calculated as a by-product of the random regression model (Jamrozik et al., 2002; Druet et al., 2005). 
In this study, persistency was defined as the breeding value on DIM 280 minus the breeding value for milk yield on DIM 80. In the definition by Jamrozik et al. (1998), DIM 80 was chosen to replace DIM 60 because average peak yield occurs in DIM 73 and DIM 65 in Luxembourg and Tunisian Holsteins, respectively (Table 1). Heritability $\left[\mathrm{h}^{2}{ }_{i(c)}\right]$ for parameter $i$ (daily, 305-d period, and persistency) in country $c$ (Luxembourg or Tunisia) was calculated as:

$$
h_{i(c)}^{2}=\frac{\sigma_{a_{i}(c)}^{2}}{\sigma_{a_{i}(c)}^{2}+\sigma_{p e_{i}(c)}^{2}+\sigma_{h y_{i}(c)}^{2}+k \times \sigma_{e(c)}^{2}} .
$$

The constant $k$ multiplying the residual variance $\left(\sigma_{e(c)}^{2}\right)$ takes the values 1,305 , or 2 when heritability is estimated for a given DIM, for a 305-d period, or for persistency, respectively. The additive genetic $\left[\sigma_{a_{i}(c)}^{2}\right]$, $\mathrm{PE}\left[\sigma_{p e_{i}(c)}^{2}\right]$, and HY $\left[\sigma_{h y_{i}(c)}^{2}\right]$ variances were computed as: $\quad \sigma_{a_{i}(c)}^{2}=\mathbf{q}_{i} \mathbf{G}_{(c)} \mathbf{q}_{i}^{\prime}, \sigma_{p e_{i}(c)}^{2}=\mathbf{q}_{i} \mathbf{P}_{(c)} \mathbf{q}_{i}^{\prime}$, and $\sigma_{h y_{i}(c)}^{2}=\mathbf{q}_{i} \mathbf{H}_{(c)} \mathbf{q}_{i}{ }^{\prime}$, respectively, where $\mathbf{q}_{i}=$ the row vector of the fourth Legendre polynomials associated with parameter $i$ and $\mathbf{G}_{(c)}, \mathbf{P}_{(c)}$, and $\mathbf{H}_{(c)}=$ parts of countryspecific covariance matrices for AG, $\mathrm{PE}$, and $\mathrm{HY}$ random regression coefficients, respectively. The vector $\mathbf{q}_{305-\mathrm{d}}$ was calculated as $\sum_{i=1}^{305} q_{i}$ and that used for persistency $\left(\mathbf{q}_{\text {pers }}\right)$ was derived as $\mathbf{q}_{280-\mathrm{d}}-\mathbf{q}_{80-\mathrm{d}}$. The genetic correlation between 305-d yield recorded on Luxembourg (l) and Tunisian (t) cows was calculated as:

$$
\mathbf{r}_{\mathrm{g} 305(\mathrm{l}, \mathrm{t})}=\frac{\mathbf{q}_{305-\mathrm{d}} \mathbf{G}_{(1, \mathrm{t})} \mathbf{q}_{305-\mathrm{d}}^{\prime}}{\sqrt{\mathbf{q}_{305-\mathrm{d}} \mathbf{G}_{(1,1)} \mathbf{q}_{305-\mathrm{d}}^{\prime}} \times \sqrt{\mathbf{q}_{305-\mathrm{d}} \mathbf{G}_{(\mathrm{t}, \mathrm{t})} \mathbf{q}_{305-\mathrm{d}}^{\prime}}},
$$

where $\mathbf{G}_{(1, \mathrm{t})}=$ the genetic covariance matrix of curve parameters for milk yield in Luxembourg and Tunisia and $\mathbf{G}_{(1,1)}$ and $\mathbf{G}_{(t, t)}=$ the genetic covariance matrices of the same curve parameters in Luxembourg and Tunisia, respectively. The genetic correlation for persistency was obtained by replacing $\mathbf{q}_{305-\mathrm{d}}$ with $\mathbf{q}_{\text {pers }}$ in the formula above.

Estimated breeding values of animals for milk yield at a given DIM (t) were computed as $\mathbf{q}_{\mathrm{t}} \hat{\mathbf{a}}_{\mathrm{s}}$, where $\hat{\mathbf{a}}_{\mathrm{s}}=$ $\left(\hat{\mathrm{a}}_{0 \mathrm{~s}}, \hat{\mathrm{a}}_{1 \mathrm{~s}}, \hat{\mathrm{a}}_{2 \mathrm{~s}}, \hat{\mathrm{a}}_{3 \mathrm{~s}}, \hat{\mathrm{a}}_{4 \mathrm{~s}}\right)$ is the vector of solutions for the additive genetic random regression coefficients of animal s. The EBV for 305-d milk yield $\left(\mathbf{E B V}_{305-\mathrm{d}}\right)$ were obtained by summing for each animal the EBV from 1 to 305
DIM. Those of persistency of lactation $\left(\mathbf{E B V}_{\text {pers }}\right)$ were calculated as $\mathrm{EBV}_{280}-\mathrm{EBV}_{80}$. Product-moment and rank correlations between EBV of sires with at least 4 daughters with records in each of the 2 countries were calculated using PROC CORR (SAS Institute, 2002).

\section{RESULTS AND DISCUSSION}

\section{Production Descriptive Parameters}

Parameters describing production systems and milk yield levels in Luxembourg and Tunisia are given in Table 1. Milk production differed between the 2 countries. A first-lactating Holstein cow in Luxembourg produced nearly $4 \mathrm{~kg}$ more milk per day than its counterpart in Tunisia. This difference summed up to $1,744 \mathrm{~kg}$ of milk over a whole lactation for all completed lactations in 2004 (ICAR, 2007). Peak yield was also greater for Luxembourg than for Tunisian first-lactation cows. Furthermore, primiparous cows in Tunisia tended to reach their peak of production earlier than those under Luxembourg management conditions (Table 1). Zwald et al. (2001) found that the number of days to peak yield was larger in countries with a high milk production level than in countries with a low milk production level. The average age at first calving was around $30 \mathrm{mo}$ in both populations. Although the frequencies of calving were nearly uniform over the year in Tunisia, they were more variable in Luxembourg, with a peak (35\%) during September to November and a decline (13\%) in the March to May period. Herd sizes were larger in Tunisia than in Luxembourg, and the average number of recorded cows per herd in Tunisia was $3 \times$ greater than that in Luxembourg in 2004 (ICAR, 2007). Luxembourg had a small average number of TD records per herd-test date class (9.4), but this level is in the range found in bordering countries. Herds in Belgium, the Netherlands, and Germany, have 5.4, 9.6, and 10.3 records per TD, on average, respectively (Zwald et al., 2001). This same parameter was 36.1 records in Tunisia, comparable to that observed on Israeli (34.0) first-lactation Holstein cows (Zwald et al., 2001).

The period of high temperatures lasts from May to September in Tunisia, with peaks during mainly the summer season. High temperature and humidity may compromise milk production of Holstein cows for a long period of time in Tunisia. In Luxembourg, only the month of August may constitute a period of discomfort for Holstein cows because of heat. Negative effects of heat stress on milk production were reported by Ravagnolo et al. (2000). Moreover, the average rainfall was greater in Luxembourg than in Tunisia. Limited water resources may constrain the quantity and quality of forage production. This may consequently hinder 
high-yielding breeds from expressing their potentials. Reproduction parameters could also be affected, which would help explain longer calving intervals in Tunisia in 2004 (ICAR, 2007).

Table 2 gives origins of common sires and maternal grandsires for both populations. Luxembourg and Tunisia had 231 common sires, with between 4 and 903 daughters. In addition, 114 maternal grandsires were in common (with at least 4 granddaughters in each country), of which 67 were also common sires. Common sires and maternal grandsires came from the United States, Canada, Germany, the Netherlands, Italy, and France. Sires from the United States and Germany were used the most among all foreign bulls. Nevertheless, some variability was observed in sire usage between the 2 countries (Hammami et al., 2007). The number of daughters from the United States common sires was greater in Tunisia, and the number of daughters of sires from Germany and the Netherlands was greater in Luxembourg.

\section{Genetic Parameters}

Posterior means of variances for AG, PE, and $\mathrm{HY}$ random regression coefficients from within- and between-country analyses are given in Table 3. Estimates obtained for Tunisia in this study were very similar to those for first-lactation milk yield obtained by Hammami et al. (2008) using a 3-trait-3-lactation random regression TD model. The AG variance estimates for the first 3 coefficients from the Luxembourg data were 46 to $69 \%$ larger than corresponding estimates from the Tunisian data. On the other hand, Tunisian $\mathrm{PE}$ variances for the same first 3 coefficients were 52 to $65 \%$ larger than Luxembourg ones. Although the joint analysis provided greater $\mathrm{AG}$ and $\mathrm{PE}$ variance estimates for the same random coefficients in both countries, proportional differences in these estimates between populations were maintained. The largest variances of PE effect in Tunisia could be due to the poor management practices and feeding fluctuations during the year, which introduce additional variation that is permanently associated with each cow compared with its counterpart in Luxembourg. On the other hand, the decreased AG variances in the Tunisian environment can be possibly caused by difficulties encountered by daughters of superior sires to express their genetic potential under harsh conditions. We can speculate that the within-herd correlations of genotype $\times$ management (essentially feeding system) in Luxembourg are large because of the available quantity and quality of forages. The most common buffer feeds [i.e., maize (Zea mays) silage and brewers grains] used in Luxembourg farms are available only for very few Tunisian farms in limited quantity and with low nutritional values.

Eigenvalues for $\mathrm{AG}$ and $\mathrm{PE}$ covariance matrices from within-country analyses are shown in Table 4 . The first principal component of the AG effect explained 86 and $89 \%$ of total variations in milk yield in Tunisia and Luxembourg, respectively. The cumulative proportion of AG variance explained by the first 3 principal components was over $98 \%$ of the total variance in each of the 2 countries. However, 4 components were needed to account for that much (98\%) variation in the PE effect. This was in agreement with Pool et al. (2000), who reported that a third-order Legendre polynomial for $\mathrm{AG}$ and a fourth polynomial for PE variances should be used to accurately model variance curves across lactation. The first 2 components accounted for 97 and 95\% of total AG variances in Luxembourg and Tunisia, respectively. These 2 components have been used to represent total yield and persistency in some studies (Jamrozik et al., 2002; Druet et al., 2005). Jamrozik et al. (2002) found only small differences with respect to the first 2 principal components among the Australian, Canadian, Italian, and New Zealand Holstein popula-

Table 2. Origin of common sires ${ }^{1}$ and maternal grandsires ${ }^{2}$ (MGS) of daughters with test-day records in Luxembourg (LUX) and Tunisia (TUN)

\begin{tabular}{|c|c|c|c|c|c|c|}
\hline \multirow[b]{3}{*}{ Country of origin } & \multicolumn{3}{|c|}{ Sires } & \multicolumn{3}{|c|}{ MGS } \\
\hline & \multicolumn{3}{|c|}{ Daughters (n) } & \multirow[b]{2}{*}{$\mathrm{n}$} & \multicolumn{2}{|c|}{ Granddaughters (n) } \\
\hline & $\mathrm{n}$ & LUX & TUN & & LUX & TUN \\
\hline Canada & 18 & 2,895 & 318 & 16 & 2,189 & 161 \\
\hline France & 16 & 516 & 84 & 1 & 4 & 19 \\
\hline Germany & 80 & 5,226 & 603 & 23 & 2,648 & 503 \\
\hline Italy & 11 & 484 & 203 & 1 & 89 & 116 \\
\hline Netherlands & 26 & 3,640 & 238 & 10 & 2,333 & 787 \\
\hline United States & 80 & 1,660 & 4,912 & 63 & 2,216 & 3,086 \\
\hline Total & 231 & 14,421 & 6,358 & 117 & 9,479 & 4,672 \\
\hline
\end{tabular}


Table 3. Posterior means of additive genetic (AG), permanent environment (PE), and herd-year (HY) variances (posterior SD in parentheses) of random regression coefficients from within-country and joint analyses for Luxembourg (LUX) and Tunisian (TUN) primiparous Holsteins

\begin{tabular}{|c|c|c|c|c|c|c|c|c|c|c|c|}
\hline \multirow[b]{2}{*}{ Variance } & \multirow[b]{2}{*}{ Country } & \multicolumn{5}{|c|}{ Within-country } & \multicolumn{5}{|c|}{ Joint analysis } \\
\hline & & $\mathrm{a}_{0}$ & $\mathrm{a}_{1}$ & $\mathrm{a}_{2}$ & $\mathrm{a}_{3}$ & $\mathrm{a}_{4}$ & $\mathrm{a}_{0}$ & $\mathrm{a}_{1}$ & $\mathrm{a}_{2}$ & $\mathrm{a}_{3}$ & $\mathrm{a}_{4}$ \\
\hline \multirow{2}{*}{$\mathrm{AG}$} & TUN & 1.95 & 0.23 & 0.11 & 0.03 & 0.02 & 2.29 & 0.34 & 0.13 & 0.04 & 0.03 \\
\hline & & $(0.01)$ & $(0.01)$ & $(0.01)$ & $(0.01)$ & $(0.01)$ & $(0.16)$ & $(0.01)$ & $(0.02)$ & $(0.01)$ & $(0.01)$ \\
\hline \multirow[t]{2}{*}{$\mathrm{PE}$} & LUX & 5.62 & 1.09 & 0.47 & 0.24 & 0.15 & 5.81 & 1.21 & 0.52 & 0.28 & 0.19 \\
\hline & & $(0.01)$ & $(0.01)$ & $(0.01)$ & $(0.01)$ & $(0.01)$ & $(0.13)$ & $(0.03)$ & $(0.02)$ & $(0.01)$ & $(0.01)$ \\
\hline \multirow[t]{4}{*}{$\mathrm{HY}$} & LUX & 0.26 & 0.20 & 0.13 & 0.05 & 0.02 & 0.26 & 0.22 & 0.13 & 0.05 & 0.02 \\
\hline & & $(0.04)$ & $(0.01)$ & $(0.01)$ & $(0.01)$ & $(0.01)$ & $(0.04)$ & $(0.01)$ & $(0.01)$ & $(0.01)$ & $(0.01)$ \\
\hline & TUN & 0.48 & 0.39 & 0.17 & 0.06 & 0.03 & 0.47 & 0.33 & 0.17 & 0.07 & 0.03 \\
\hline & & $(0.01)$ & $(0.01)$ & $(0.01)$ & $(0.01)$ & $(0.01)$ & $(0.08)$ & $(0.04)$ & $(0.01)$ & $(0.01)$ & $(0.01)$ \\
\hline
\end{tabular}

tions when using fourth-order Legendre polynomials. Based on a random regression TD model with the same order of Legendre polynomials, Druet et al. (2005) also found that the first 2 components explained more than $95 \%$ of variation. They used only 2 eigenvectors, associated with the first 2 eigenvalues, as covariates to estimate covariance components of daily milk traits in French Holsteins. In this study (Table 4), a very large proportion of the AG variances (99\% for Luxembourg, 98\% for Tunisia) was explained by the first 3 eigenvalues, and the relatively small eigenvalues for higher orders show that the rank reduction of the actual model by using only the third order for the AG part may be sensible. On the other hand, a relatively smaller proportion of the $\mathrm{PE}$ variance (95\% for both countries)

Table 4. Eigenvalues (EIG) and their relative proportions (PROP) for additive genetic (AG), permanent environment (PE), and herd-year effect $(\mathrm{HY})$ covariance matrices from analyses within Luxembourg (LUX) and Tunisia (TUN)

\begin{tabular}{lcccccc}
\hline & & \multicolumn{2}{c}{ LUX } & & \multicolumn{2}{c}{ TUN } \\
\cline { 3 - 4 } \cline { 5 - 6 } Item & & EIG & PROP & & EIG & PROP \\
\hline AG & 1 & 4.33 & 0.89 & & 2.01 & 0.86 \\
& 2 & 0.37 & 0.08 & & 0.21 & 0.09 \\
& 3 & 0.11 & 0.02 & & 0.08 & 0.03 \\
& 4 & 0.02 & 0.01 & & 0.02 & 0.01 \\
& 5 & 0.01 & 0.00 & & 0.02 & 0.01 \\
$\mathrm{PE}$ & 1 & 5.67 & 0.75 & & 8.61 & 0.71 \\
& 2 & 1.07 & 0.14 & & 1.92 & 0.16 \\
& 3 & 0.49 & 0.07 & & 0.97 & 0.08 \\
& 4 & 0.26 & 0.03 & & 0.51 & 0.04 \\
$\mathrm{HY}$ & 5 & 0.08 & 0.01 & & 0.05 & 0.01 \\
& 1 & 0.37 & 0.55 & & 0.70 & 0.62 \\
& 2 & 0.18 & 0.27 & & 0.24 & 0.21 \\
& 3 & 0.09 & 0.14 & & 0.16 & 0.14 \\
& 4 & 0.02 & 0.03 & & 0.02 & 0.02 \\
& 5 & 0.01 & 0.01 & & 0.01 & 0.01 \\
\hline
\end{tabular}

was explained by the first 3 eigenvalues. These results could indicate that $\mathrm{PE}$ effect should be modeled with at least one order Legendre polynomials more than that for AG effect. The HY effect was intermediate (96\% for Luxembourg, 97\% for Tunisia); therefore, it seems that modeling the HY effect could require the same or one order more than that used for the AG effect.

Posterior means of heritability estimates of 305-d yield and persistency as defined in this study for first lactation obtained from univariate and bivariate (Luxembourg and Tunisia used as 2 separate traits) analyses are given in Table 5. Heritabilities obtained from the joint analysis were larger than those obtained from separate analyses. Tunisia had consistently smaller heritabilities than Luxembourg for milk yield and persistency. For instance, heritability for 305-d yield in Tunisia was 53\% lower than that in Luxembourg. Ojango and Pollott (2002) reported that heritability estimates for 305-d milk yield in Kenya were $42 \%$ lower than that in the United Kingdom when doing a joint analysis. Carabaño et al. (1989) also found that Spanish first-lactation 305-d milk yield heritability estimated using a sire lactation model ( 0.16 from within Spain and 0.12 from between Spain and the US analyses) was smaller than that found in the US population (0.33 from within the United States and 0.26 from between Spain and the US analyses). These authors concluded that low heritability estimates obtained for the Spanish Holsteins were caused by poor management conditions. Differences in heritabilities between Luxembourg and Tunisia may be caused by differences in production levels resulting from differences in climatic conditions and management. Jamrozik et al. (2002) also reported variable estimates of lactation curve parameters among countries with different production systems. These authors linked differences 
Table 5. Posterior means (posterior SD in parentheses) of heritabilities $\left(\mathrm{h}^{2}\right)$ of $305-\mathrm{d}$ milk yield and persistency ${ }^{1}$ of first lactation and correlations ${ }^{2}$ between EBV of common sires ${ }^{3}$ from within-country and joint analyses in Luxembourg (LUX) and Tunisian (TUN) Holsteins

\begin{tabular}{|c|c|c|c|c|c|c|c|}
\hline Parameters & \multicolumn{4}{|c|}{ Within-country analysis } & \multicolumn{3}{|c|}{ Joint analysis } \\
\hline 305-d milk yield & $\begin{array}{c}0.41 \\
(0.01)\end{array}$ & $\begin{array}{c}0.17 \\
(0.01)\end{array}$ & 0.38 & 0.41 & $\begin{array}{c}0.42 \\
(0.01)\end{array}$ & $\begin{array}{c}0.19 \\
(0.02)\end{array}$ & $\begin{array}{c}0.60 \\
(0.03)\end{array}$ \\
\hline Persistency & $\begin{array}{c}0.11 \\
(0.02)\end{array}$ & $\begin{array}{c}0.06 \\
(0.01)\end{array}$ & 0.27 & 0.26 & $\begin{array}{c}0.12 \\
(0.02)\end{array}$ & $\begin{array}{c}0.08 \\
(0.02)\end{array}$ & $\begin{array}{c}0.36 \\
(0.04)\end{array}$ \\
\hline
\end{tabular}

${ }^{1}$ Persistency defined as EBV at DIM $280-$ EBV at DIM 80.

${ }^{2} r_{\mathrm{m}}=$ the product moment correlation; $\mathrm{r}_{\mathrm{s}}=$ the rank correlation; and $\mathrm{r}_{\mathrm{g}}=$ the genetic correlation.

${ }^{3}$ Common sires were defined as sires with at least 4 daughters in each country.

in estimates not only to absolute production levels but also to relationships among lactation curve parameters found for any given population. Persistency as defined by Jamrozik et al. (2002) clearly depended on production levels of the considered population. Heritability estimates of persistency for both populations were lower than the 0.30 reported by Jamrozik et al. (1998) for the Canadian Holsteins using the linear slope between yields at DIM 60 and DIM 280 as a measure of persistency. Low heritability of persistency obtained in Tunisia could reflect difficulties encountered by cows to maintain high milk production after the peak, thereby suppressing expression of genetic variance.

Posterior means of genetic correlations for 305-d milk yield and lactation persistency from the joint analysis are shown in Table 5. The genetic correlation between Luxembourg and Tunisian 305-d milk yields (0.60) was low compared with estimates in some studies (Weigel et al., 2001; Jamrozik et al., 2002). Jamrozik et al. (2002) reported genetic correlations for total (mostly 305-d) milk yield. Results ranged from 0.66 to 0.83 among Australian, New Zealand, Canadian, and Italian first-lactation Holsteins using a random regression TD animal model. Likewise, Weigel et al. (2001) reported values greater than 0.80 between total yield correlation estimates obtained by a multitrait analysis of 16 million first-lactation records from 17 Interbull country members. Estimates reported by Weigel et al. (2001) were $>0.90$ between countries with predominantly grazing systems (Ireland, Australia, and New Zealand). Those correlations were greater than 0.91 among countries with high milk production levels (United States, Canada, Belgium, the Netherlands, and Italy). Correlations between total yields in the remaining Interbull countries ranged between 0.80 and 0.90 (Weigel et al., 2001). The genetic correlation between 305-d milk yields in Luxembourg and Tunisia is still in the range of estimates obtained between pairs of countries known with harsh climatic conditions or diverse production systems (e.g., the genetic correlation between the United Kingdom and Kenya was only 0.49; Ojango and Pollott, 2002). Cienfuegos-Rivas et al. (1999) reported a genetic correlation of 0.63 between the United States and Mexico. A slightly larger genetic correlation (0.66) between Italy and New Zealand was reported by Jamrozik et al. (2002). The genetic correlation between persistency, as defined in this study, in Luxembourg and Tunisia was 0.36 , which is lower than 0.55 obtained between the Canadian and Italian firstlactation cows in a study of 4 populations (Jamrozik et al., 2002), in which persistency was defined as a byproduct of the random regression model. These authors found the lowest estimate (0.16) between the Italian and New Zealand Holsteins. According to Robertson (1959), low genetic correlations suggest evidence of G $\times$ E. In this study, low genetic correlations $(<0.80)$ between parameters (305-d milk yield and persistency) of Tunisian and Luxembourg first lactation indicate that superior animals on a trait in one environment are not necessarily as superior in the other and vice versa.

\section{$G \times E$}

Genetic variances and heritability estimates revealed unequal genetic expression of Holstein genes under Luxembourg and Tunisian management circumstances. Several studies (Veerkamp and Goddard, 1998; Gengler et al., 2005) reported that the genetic variance for milk yield is greater in high-input systems compared with that in low-input systems. Others (Raffrenato et al., 2003; Ben Gara et al., 2006) found low genetic variance and heritability estimates for production traits under low-input production environments. Low genetic variances for milk yield throughout lactation observed in Tunisian Holsteins translate into smaller differences in breeding values among animals. Performances of cows in Tunisia are limited because of harsh climatic conditions (discomfort) and limited feed 


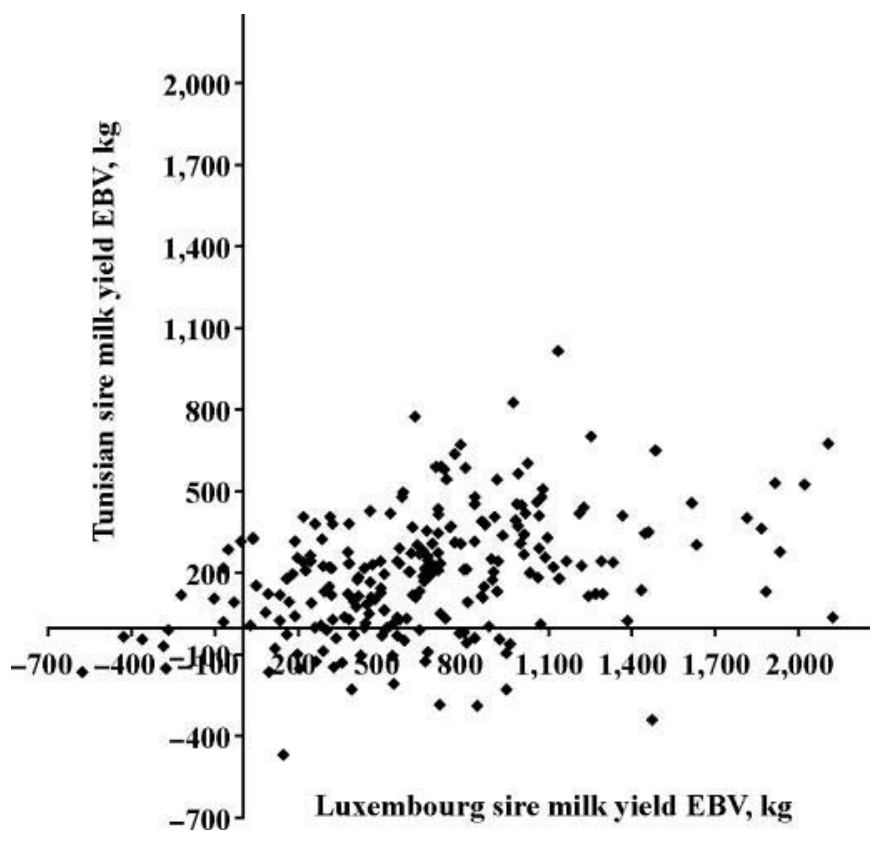

Figure 1. Plots of first-lactation EBV of common sires, defined as sires with at least 4 daughters in each country, for 305-d milk yield in Tunisia against their EBV in Luxembourg.

resources compared with less constraining factors in Luxembourg, where cows are managed under conditions similar to those where their sires were selected. Currently, $70 \%$ of total bulls used in the Luxembourg cow population were selected in bordering countries with production conditions similar to those found in Luxembourg. Selection responses to the use of US Holstein sires for milk production in Latin America were estimated to be 53 to $78 \%$ of the response observed in the United States (Stanton et al., 1991). The relative response to sire selection expected in Kenya based on United Kingdom breeding values was only about $44 \%$ (Ojango and Pollott, 2002). Therefore, environmental factors appear to constrain expression of genetic merit in tropical or subtropical regions relying on imported proven Holstein semen.

Differences in additive genetic variances obtained for Luxembourg and Tunisian populations imply that a scaling effect exists for EBV of sires across these environments. Low genetic and rank correlations translate a reranking of sires across these populations. Tunisian EBV of sires for 305-d yields were regressed on corresponding Luxembourg values. Figure 1 shows a plot of these milk yield EBV of the 231 common sires estimated in Tunisia against their EBV in Luxembourg. The slope (b) in the regression equation could be viewed as the expected response measured on daughters in Tunisia from sire selection on EBV in Luxembourg.
This regression coefficient was only 0.18 in the current study. This result is less than that $(b=0.32)$ reported by Ojango and Pollott (2002) from regressing EBV of sires in Kenya on the EBV of the same sires in the United Kingdom. The expected response $(b=0.57)$ measured on daughters of US sires in the low-input Mexican environment was less than responses of daughters of the same US sires in all US environments (Stanton et al., 1991). These authors concluded that the US Holstein genes had restrained expression under the Mexican management circumstances.

Product moment and rank correlations (Table 5) between $\mathrm{EBV}_{305-\mathrm{d}}$ from within-country analyses were lower than corresponding genetic correlations (0.60). Cienfuegos-Rivas et al. (1999) also found low rank correlation coefficient $(0.59)$ between herds in low milk production level in Mexico and all herds in the United States. They concluded that this result was evidence for a significant $\mathrm{G} \times \mathrm{E}$ interaction and that sires were ranked differently in the Mexican environment compared with their ranking in the United States. Figure 2 shows the $\mathrm{EBV}_{305-\mathrm{d}}$ of 15 common sires with more than 30 daughters in Luxembourg. It appears that considerable reranking of bulls with respect to milk yield was observed. Moreover, product moment and rank correlation based only on these 15 sires were around 0.42 . Restricting computation to only this group of sires did not cause any significant change in correlation estimates between EBV found in Luxembourg and Tunisia. Mulder et al. (2004) reported that the reranking effect is most likely observed with top sires. As on milk yield $\mathrm{EBV}_{305-\mathrm{d}}$, there were also differences in the ranking of sires on $\mathrm{EBV}_{\text {pers }}$ between the 2 environments (Table 6). Product moment (0.27) and rank correlations (0.26) between $\mathrm{EBV}_{\text {pers }}$ from within-country analyses were lower than those between $\mathrm{EBV}_{305-\mathrm{d}}$ (Table 5). Moreover, the rank correlation between Tunisian sire $\mathrm{EBV}_{305-\mathrm{d}}$ and Luxembourg sire $\mathrm{EBV}_{\text {pers }}$ was 0.21 , and that between Luxembourg sires $\mathrm{EBV}_{305-\mathrm{d}}$ and Tunisian $\mathrm{EBV}_{\text {pers }}$ was 0.29 . These low correlations indicate that superior animals for 305-d milk yield are not necessarily as superior for persistency of lactation. These results may also imply that animals with high $305-d$ yield in a favorable environment may have lower yield but greater persistency in a less favorable environment.

In general, results from this study indicated potential interactions between genotype and environment for 305-d milk yield and persistency in Holsteins. That is, potential benefits from importing superior germplasm would be decreased in limited input production systems. Peterson (1988) reported that a reranking effect was observed for Canadian sires when used in New Zealand. The authors suspected this is caused by 


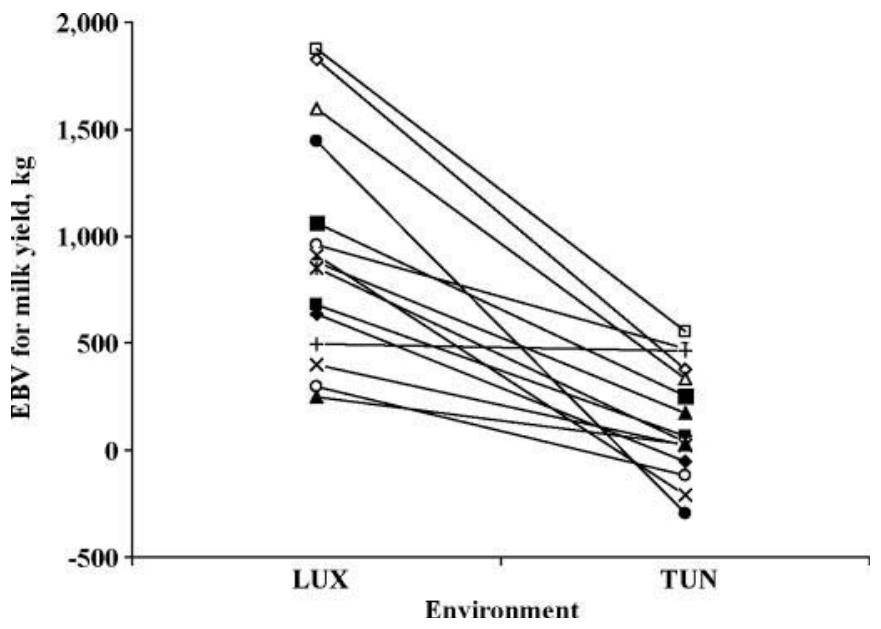

Figure 2. Estimated breeding values for first-lactation 305-d milk yield of 15 sires with at least 30 daughters each in Luxembourg (LUX). TUN = Tunisia.

the decreased ability of daughters of Canadian sires to get sufficient energy intakes from exclusive pasture regimens in New Zealand. Cienfuegos-Rivas et al. (1999) concluded that significant $\mathrm{G} \times \mathrm{E}$ was found for milk yield using Mexican and US Holsteins. These authors reported that only cows in US low-producing environments were able to predict performances of their paternal half-sisters in Latin American countries in agreement with reports by Stanton et al. (1991) and Costa et al. (2000). They also suggested that investing in imported semen without testing this germplasm under local circumstances is probably inappropriate in certain low-input environments.

\section{CONCLUSIONS}

Genetic parameters of lactation curves were obtained from single and joint analyses of Luxembourg and Tunisian data by a random regression TD animal model using a fourth-order Legendre polynomial. The AG variance estimates from the Luxembourg data were larger than corresponding estimates from the Tunisian data, whereas Tunisian PE variances were greater than Luxembourg ones, reflecting differences in production levels and environments. Genetic parameters of lactation curves revealed differences in gene expressions between Luxembourg and Tunisian Holsteins. A high heritability for 305-d milk yield and a moderate one for persistency found in Luxembourg Holsteins give more possibilities for selection and genetic progress under their producing environments. On the other hand, the Tunisian constraining conditions including climatic, health stressors, and feeding limitations impede the expression of superior genes for milk production and thus may decrease potential gains from selection. Genetic correlations between Luxembourg and Tunisia for 305-d milk yield and persistency were in the same range as estimates obtained between pairs of countries known for important differences in climates and production systems. Rank correlations and regression coefficients obtained on sires EBV for milk yield from within Luxembourg and Tunisia analyses were lower than genetic correlations found by the joint analysis. Low correlations are evidence for $\mathrm{G} \times \mathrm{E}$. Moreover, sires used in Luxembourg and Tunisia were ranked differently in the 2 environments. Results suggest that Holsteins selected in favorable environments will not perform as well in less favorable management

Table 6. Estimated breeding values for $305-\mathrm{d}$ milk yield and persistency ${ }^{1}$ of lactation for common sires with more than 30 daughters in Luxembourg

\begin{tabular}{|c|c|c|c|c|c|c|}
\hline \multirow[b]{2}{*}{ Sires } & \multicolumn{3}{|c|}{ Luxembourg } & \multicolumn{3}{|c|}{ Tunisia } \\
\hline & 305-d milk yield & Persistency & Daughters (n) & 305-d milk yield & Persistency & Daughters (n) \\
\hline S2 & $1,827.43$ & 0.43 & 113 & 377.41 & 0.65 & 124 \\
\hline S3 & $1,597.63$ & 0.42 & 35 & 337.35 & 0.04 & 33 \\
\hline $\mathrm{S} 4$ & $1,444.13$ & -0.68 & 33 & -295.79 & 1.89 & 56 \\
\hline S5 & $1,063.02$ & 0.96 & 32 & 256.88 & 1.19 & 410 \\
\hline S8 & 879.55 & 0.12 & 235 & 171.02 & 0.53 & 100 \\
\hline S9 & 850.67 & -2.69 & 660 & 39.92 & -0.70 & 29 \\
\hline S10 & 677.83 & 0.04 & 227 & 67.29 & 0.80 & 26 \\
\hline S11 & 634.24 & -0.46 & 512 & -54.28 & 0.05 & 44 \\
\hline S12 & 495.16 & 0.13 & 91 & 464.65 & 0.12 & 93 \\
\hline S13 & 401.77 & 0.03 & 297 & 23.99 & 0.47 & 20 \\
\hline S14 & 297.56 & -0.19 & 71 & -116.09 & -1.11 & 35 \\
\hline
\end{tabular}

${ }^{1}$ Persistency was defined as EBV at DIM 280 - EBV at DIM 80. 
conditions. They also suggest that low- to mediuminput production systems should consider the use of semen of sires selected in regions with low to medium producing environment in countries with leading dairy industries if they were not able to select from their own populations. Finally, even if rankings between animals might change by going from one environment to the other, the correlations estimated across countries were positive, and the greater selection intensity in temperate regions still likely makes these animals genetically superior for milk yield, on average, even in different environments, provided that sufficient feeding and management are provided. However results (i.e., $r_{g}$ $\leq 0.60$ ) showed that paying premium prices for elite animals from temperate environments or semen from those animals is not necessarily a good strategy. The issue is to transfer correctly the genetic progress from temperate high-input levels into different environments. Moreover, importing countries should use more effort to meet the elementary needs of high-yielding breeds under their conditions.

\section{ACKNOWLEDGMENTS}

Funding from the Luxembourg Ministry of Culture, Higher Education and Research (BFR04/061) and Gembloux Agricultural University is deeply acknowledged. Thanks to CONVIS Herdbuch, Service Elevage et Génétique and the Tunisian Livestock and Pasture Office for providing data. The first author and Nicolas Gengler acknowledge the support of the National Fund for Scientific Research (Brussels, Belgium) through grants F.4552.05 and 2.4507.02 F (2). The assistance of G. R. Wiggans, Animal Improvement Programs Laboratory (Beltsville, MD) in manuscript review is appreciated.

\section{REFERENCES}

Banos, G., and C. Smith. 1991. Selecting bulls across countries to maximize genetic improvement in dairy cattle. J. Anim. Breed. Genet. 108:174-181

Beerda, B., W. Ouweltjes, L. B. J. Sebek, J. J. Windig, and R. F. Veerkamp. 2007. Effects of genotype by environment interactions on milk yield, energy balance, and protein balance. J. Dairy Sci. 90:219-228.

Ben Gara, A., B. Rekik, and M. Bouallègue. 2006. Genetic parameters and evaluation of the Tunisian dairy cattle population for milk yield by Bayesian and BLUP analyses. Livest. Prod. Sci. 100:142-149.

Calus, M. P. L., A. F. Groen, and G. de Jong. 2002. Genotype $\times$ environment interaction for protein yield in Dutch dairy cattle as quantified by different models. J. Dairy Sci. 85:3115-3123.

Carabaño, M. J., L. D. Van Vleck, and G. R. Wiggans. 1989. Estimation of genetic parameters for milk and fat yields of dairy cattle in Spain and the United States. J. Dairy Sci. 72:3013-3022.

Cienfuegos-Rivas, E. G., P. A. Oltenacu, R. W. Blake, S. J. Schwager, H. Castillo-Juarez, and F. J. Ruiz. 1999. Interaction between milk yield of Holstein cows in Mexico and the United States. J. Dairy Sci. 82:2218-2223.

Costa, C. N., R. W. Blake, E. J. Pollak, P. A. Oltenacu, R. L. Quaas, and S. R. Searle. 2000. Genetic analysis of Holstein cattle populations in Brazil and the United States. J. Dairy Sci. 83:2963-2974.

Druet, T., F. Jaffrézic, and V. Ducrocq. 2005. Estimation of genetic parameters for test-day records of dairy traits in the first three lactations. Genet. Sel. Evol. 37:257-271.

Fahey, A. G., M. M. Schutz, D. L. Lofgren, A. P. Schinckel, and T. S. Stewart. 2007. Genotype by environment interaction for production traits while accounting for heteroscedasticity. J. Dairy Sci. 90:3889-3899.

Freemeteo. 2007. Average (1961-1990). http://www.freemeteo.com. Accessed Dec. 21, 2007.

Gengler, N. 1996. Persistency of lactation yields: A review. Interbull Bull. 12:97-102

Gengler, N., G. R. Wiggans, and A. Gillon. 2005. Adjustment for heterogeneous covariance due to herd milk yield by transformation of test-day random regressions. J. Dairy Sci. 88:2981-2990.

Hammami, H., C. Croquet, J. Stoll, B. Rekik, and N. Gengler. 2007. Genetic diversity and joint-pedigree analysis of two importing Holstein populations. J. Dairy Sci. 90:3530-3541.

Hammami, H., B. Rekik, H. Soyeurt, A. Ben Gara, and N. Gengler. 2008. Genetic parameters of Tunisian Holsteins using a test-day random regression model. J. Dairy Sci. 91:2118-2126.

ICAR. 2007. Yearly milk enquiry. http://www.waap.it/enquiry. Accessed Oct. 2, 2007.

Jamrozik, J., G. Jansen, L. R. Schaeffer, and Z. Liu. 1998. Analysis of persistency of lactation calculated from a random regression test day model. Interbull Bull. 16:43-47.

Jamrozik, J., L. R. Schaeffer, and K. A. Weigel. 2002. Estimates of genetic parameters for single- and multiple-country test-day models. J. Dairy Sci. 85:3131-3141.

Miglior, F., B. L. Muir, and B. J. Van Doormaal. 2005. Selection indices in Holstein cattle of various countries. J. Dairy Sci $88: 1255-1263$

Misztal, I., S. Tsuruta, T. Strabel, B. Auvray, T. Druet, and D. H. Lee. 2002. BLUPF90 and related programs (BGF90). Proc. 7th World Congr. Genet. Appl. Livest. Prod., Montpellier, France. CD-ROM Commun. 28:07.

Mulder, H. A., A. F. Groen, G. de Jong, and P. Bijma. 2004. Genotype by environment interaction for yield and somatic cell score with automatic and conventional milking systems. J. Dairy Sci 87:1487-1495.

Ojango, J. M. K., and G. E. Pollott. 2002. The relationship between Holstein bull breeding values for milk yield derived in both the UK and Kenya. Livest. Prod. Sci. 74:1-12.

Payne, W. J. A., and J. Hodges. 1997. Tropical Cattle. Origin, Breeds and Breeding Policies. Blackwell Science, Boston, MA

Peterson, R. 1988. Comparison of Canadian and New Zealand sires in New Zealand for production, weight, and conformation traits. Research bulletin no. 5. Livestock Improvement Corporation, Hamilton, New Zealand.

Pool, M. H., L. L. G. Janss, and T. H. E. Meuwissen. 2000. Genetic parameters of Legendre polynomials for first-parity lactation curves. J. Dairy Sci. 83:2640-2649.

Raffrenato, E., R. W. Blake, P. A. Oltenacu, J. Carvalheiro, and G. Licitra. 2003. Genotype by environment interaction for yield and somatic cell score with alternative environmental definitions. J. Dairy Sci. 86:2470-2479.

Ravagnolo, O., I. Misztal, and G. Hoogenboom. 2000. Genetic component of heat stress in dairy cattle, development of heat index function. J. Dairy Sci. 83:2120-2125.

Robertson, A. 1959. The sampling variance of the genetic correlation coefficient. Biometrics 15:469-485.

SAS Institute. 2002. SAS User's Guide. Statistics. Version 9.1.3 Edition. SAS Institute Inc., Cary, NC.

Stanton, T. L., R. W. Blake, R. L. Quaas, L. D. Van Vleck, and M. J. Carabaño. 1991. Genotype by environment interaction for Holstein milk yield in Colombia, Mexico, and Puerto Rico. J. Dairy Sci. 74:1700-1714. 
Veerkamp, R. F., and M. E. Goddard. 1998. Covariance functions across herd production levels for test day records on milk, fat, and protein yields. J. Dairy Sci. 81:1690-1701.

Veerkamp, R. F., G. Simm, and J. D. Oldham. 1995. Genotype by environment interactions: Experience from Langhill. In Breeding and Feeding the High Genetic Merit Dairy Cow. Br. Soc. Anim. Sci. Occas. Publ. 19:59-66.

Weigel, K. A., R. Rekaya, N. R. Zwald, and W. F. Fikse. 2001. International genetic evaluation of dairy sires using a multipletrait model with individual animal performance records. J. Dairy Sci. 84:2789-2795.
Zwald, N. R., K. A. Weigel, W. F. Fikse, and R. Rekaya. 2001. Characterization of dairy production systems in countries that participate in the international bull evaluation service. J. Dairy Sci. 84:2530-2534.

Zwald, N. R., K. A. Weigel, W. F. Fikse, and R. Rekaya. 2003. Application of a multiple-trait herd cluster model for genetic evaluation of dairy sires from seventeen countries. J. Dairy Sci. $86: 376-382$ 